\title{
Inhibitory effect of green coffee bean extract on fat accumulation and body weight gain in mice Hiroshi Shimoda*, Emi Seki and Michio Aitani
}

\author{
Address: Oryza Oil \& Fat Chemical Co., Ltd., Research \& Development Division, 1 Numata Kitagata-cho, Ichinomiya, Aichi 493-8001, Japan \\ Email: Hiroshi Shimoda* - kaihatsu@mri.biglobe.ne.jp; Emi Seki - kaihatsu@mri.biglobe.ne.jp; Michio Aitani - kaihatsu@mri.biglobe.ne.jp \\ * Corresponding author
}

Published: 17 March 2006

BMC Complementary and Alternative Medicine 2006, 6:9 doi:10.1 186/1472-6882-6-9

This article is available from: http://www.biomedcentral.com/l472-6882/6/9

(c) 2006 Shimoda et al; licensee BioMed Central Ltd.

This is an Open Access article distributed under the terms of the Creative Commons Attribution License (http://creativecommons.org/licenses/by/2.0), which permits unrestricted use, distribution, and reproduction in any medium, provided the original work is properly cited.
Received: 16 May 2005

Accepted: 17 March 2006

\begin{abstract}
Background: An epidemiological study conducted in Italy indicated that coffee has the greatest antioxidant capacity among the commonly consumed beverages. Green coffee bean is rich in chlorogenic acid and its related compounds. The effect of green coffee bean extract (GCBE) on fat accumulation and body weight in mice was assessed with the objective of investigating the effect of GCBE on mild obesity.
\end{abstract}

Methods: Male ddy mice were fed a standard diet containing GCBE and its principal constituents, namely, caffeine and chlorogenic acid, for 14 days. Further, hepatic triglyceride (TG) level was also investigated after consecutive administration ( 13 days) of GCBE and its constituents. To examine the effect of GCBE and its constituents on fat absorption, serum TG changes were evaluated in olive oil-loaded mice. In addition, to investigate the effect on hepatic TG metabolism, carnitine palmitoyltransferase (CPT) activity in mice was evaluated after consecutive ingestion (6 days) of GCBE and its constituents (caffeine, chlorogenic acid, neochlorogenic acid and feruloylquinic acid mixture).

Results: It was found that $0.5 \%$ and I\% GCBE reduced visceral fat content and body weight. Caffeine and chlorogenic acid showed a tendency to reduce visceral fat and body weight. Oral administration of GCBE ( 100 and $200 \mathrm{mg} / \mathrm{kg}$. day) for 13 days showed a tendency to reduce hepatic TG in mice. In the same model, chlorogenic acid $(60 \mathrm{mg} / \mathrm{kg}$. day) reduced hepatic TG level. In mice loaded with olive oil $(5 \mathrm{~mL} / \mathrm{kg}), \mathrm{GCBE}(200$ and $400 \mathrm{mg} / \mathrm{kg})$ and caffeine $(20$ and $40 \mathrm{mg} / \mathrm{kg})$ reduced serum TG level. GCBE (I\%), neochlorogenic acid $(0.028 \%$ and $0.055 \%)$ and feruloylquinic acid mixture $(0.081 \%)$ significantly enhanced hepatic CPT activity in mice. However, neither caffeine nor chlorogenic acid alone was found to enhance CPT activity.

Conclusion: These results suggest that GCBE is possibly effective against weight gain and fat accumulation by inhibition of fat absorption and activation of fat metabolism in the liver. Caffeine was found to be a suppressor of fat absorption, while chlorogenic acid was found to be partially involved in the suppressive effect of GCBE that resulted in the reduction of hepatic TG level. Phenolic compounds such as neochlorogenic acid and feruloylquinic acid mixture, except chlorogenic acid, can enhance hepatic CPT activity. 


\section{Background}

Coffee is one of the most commonly consumed beverages worldwide. However, the stimulating effect of caffeine on the central nervous system has significantly reduced the frequency of consumption due to its side effects on the cardiovascular system [1], central nervous system [2], and endocrine system [3]. On the other hand, scientific studies have revealed that both coffee and caffeine play a preventive role against various degenerative diseases of modern society. Van Dam and Feskens [4] reported that moderate daily consumption of coffee helped to reduce the risk of type 2 diabetes, while Fredholm and Lindgren found that caffeine promotes lipolysis in rat adipocytes [5]. Human studies show that caffeine enhances energy expenditure [6] and improves the clinical conditions of diabetic patients $[7,8]$. Another study by Greer $e t$ al. revealed that caffeine ingestion promotes glucose consumption with an increase in blood epinephrine [9], while pre-exercise consumption promotes ventilation and enhances lipolysis [10]. Chlorogenic acid, another main constituent of coffee beans, has recently been reported to selectively inhibit hepatic glucose-6-phosphatase [11], which is a rate-limiting enzyme involved in gluconeogenesis. However, roasting of coffee beans has been shown to reduce the content of chlorogenic acid in coffee [12]. Green coffee beans are rich in chlorogenic acid and its related compounds that show hypotensive effect [13]. In the present study, the effect of green coffee bean extract (GCBE) and its principal constituents on mice body weight and visceral fat contents were investigated. In addition, the effect of GCBE on fat absorption and metabolism were examined.

\section{Methods \\ Animals}

Male ddy mice (Japan SLC Inc., Shizuoka, Japan) were used for the experiments. The animals were housed at $23^{\circ} \mathrm{C} \pm 1^{\circ} \mathrm{C}$ and were fed standard non-purified diet (CE2, Clea Japan Inc., Shizuoka, Japan) and tap water ad libitum. The experiments were conducted in accordance with the Guidelines for Animal Experimentation (Japan Association for Laboratory Animal Science, 1987). All experimental designs were approved by the Ethical Committee for Use of Experimental Animals.

\section{Preparation and determination of GCBE}

GCBE (yield: $13.7 \%$ ) was extracted from green coffee (coffea canephora) beans at $70^{\circ} \mathrm{C}$ for $2 \mathrm{~h}$ using $70 \%$ ethanol. Caffeine, chlorogenic acid and its related compounds were analysed by HPLC using anhydrous caffeine (Kishida Chemical Co., Ltd., Osaka, Japan) and chlorogenic acid (Sigma-Aldrich Co., Ltd., St. Louis, MO, USA) as standards (Figure 1). HPLC equipped with a Capcellpack C18 $(4.6 \phi \times 250 \mathrm{~mm}$, Shiseido, Tokyo, Japan $)$ and a photodiode array detector (SPD-10 Avp, Shimadzu, Kyoto, Japan) was used. The solvent used included (A) $2 \mathrm{mM} \mathrm{H}_{3} \mathrm{PO}_{4}$ and
(B) $\mathrm{CH}_{3} \mathrm{CN}$; a linear gradient of (A) was changed to (B) after $35 \mathrm{~min}$. The flow rate was maintained at $1.0 \mathrm{~mL} / \mathrm{min}$. The amounts of caffeine and chlorogenic acid detected were $10.0 \%$ and $27.0 \%$. As shown in Figure 2, GCBE contains chlorogenic acid and other related compounds, namely, 3-caffeoylquinic acid (neochlorogenic acid) and a mixture of feruloylquinic acids. These compounds were isolated and identified from GCBE [14]. The amounts of 3-caffeoylquinic acid and a mixture of feruloylquinic acids using standard chlorogenic acid were $5.5 \%$ and $16.0 \%$. The content of 4,5 -dicaffeoylquinic acid was $5.2 \%$ using an authentic sample which was isolated from Japanese butterbur.

\section{Reagents}

Sesamin (Industrial Research, Ltd., Wellington, New Zealand) and orlistat (Hoffman-La Roche Ltd., Basel, Switzerland) were used as reference compounds. EDTA was purchased from Kishida Chemical Co., Ltd. (Osaka, Japan), while palmitoyl CoA and L-carnitine were obtained from Sigma-Aldrich Co., Ltd. (MA, USA). Calcium and magnesium-free phosphate buffered saline [PBS $(-)]$, Triglyceride E-test Wako, olive oil, sucrose, Triton X100 and 5,5'-dithiobis(2-nitrobenzoate) (DTNB) were purchased from Wako Pure Chemicals Industries, Ltd., Osaka, Japan.

\section{Measurements of mice body weight and visceral fats}

Six week-old mice were given free access to nonpurified diet (CE-2) containing $0.5 \%$ or $1 \%$ GCBE for 14 days. Caffeine $(0.05 \%$ and $0.1 \%)$ and chlorogenic acid $(0.15 \%$ and $0.3 \%$ ) were added to the diet. Mice were weighed every 2 days. Mice epididymal and perirenal fats were removed and weighed at the end of the experiment. Orlistat, a medicine prescribed for obesity, was used as a positive control.

\section{Measurements of hepatic triglyceride level in mice}

Acacia gum (5\%) suspension containing GCBE (100 and $200 \mathrm{mg} / \mathrm{kg} \cdot$ day $)$, caffeine (10 and $20 \mathrm{mg} / \mathrm{kg}$ - day) and chlorogenic acid (30 and $60 \mathrm{mg} / \mathrm{kg}$. day) was administered daily to 5 week-old mice for 13 days. On day 14 , the livers were removed and approximately $200 \mathrm{mg}$ of the liver was homogenized in $1 \mathrm{~mL}$ of PBS (-). This suspension was then centrifuged $(2200 \times \mathrm{g}, 10 \mathrm{~min})$, followed by the extraction of hepatic triglyceride (TG) using a mixture of chloroform and methanol (2:1). The extract was evaporated and resuspended in $1 \mathrm{~mL}$ PBS (-). The TG content was measured using Triglyceride E-test Wako. Sesamin was used as a positive control.

\section{Determination of serum TG in olive oil-loaded mice}

The experiments were carried out as described by Shimoda et al. [15]. Initial blood samples were collected from infraorbital venous plexus of mice (aged 5 to 6 weeks) after fasting for 20-22 h. The mice were administered with 


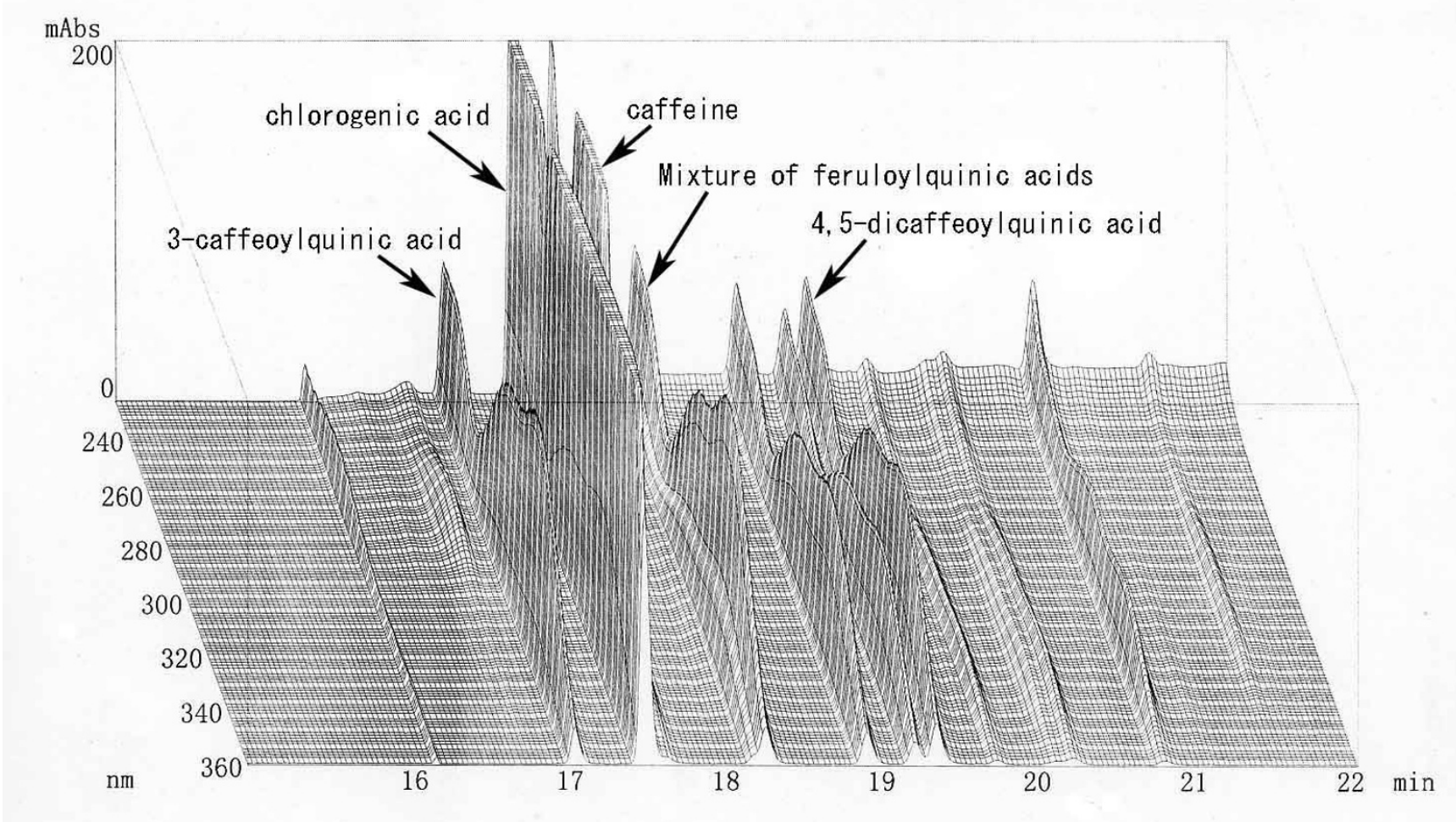

Figure I

Three dimensional HPLC chromatogram of GCBE.

an acacia gum (5\%) suspension containing GCBE (200 and $400 \mathrm{mg} / \mathrm{kg}$ ), caffeine (20 and $40 \mathrm{mg} / \mathrm{kg}$ ) and chlorogenic acid ( 60 and $120 \mathrm{mg} / \mathrm{kg}$ ). After $30 \mathrm{~min}$, olive oil (5 $\mathrm{mL} / \mathrm{kg}$ ) was administered to the mice. Blood samples were collected at intervals of $2 \mathrm{~h}$ after loading with olive oil. The samples were centrifuged and serum TG was measured using Triglyceride E-test Wako. Orlistat was used as a positive control.

\section{Measurements of hepatic carnitine palmitoyltransferase activity in mice}

Six week-old mice were fed a diet (CE-2) containing GCBE $(0.5 \%$ and $1 \%)$, caffeine $(0.05 \%$ and $0.1 \%)$, chlorogenic acid $(0.15 \%$ and $0.3 \%)$, neochlorogenic acid $(0.028 \%$ and $0.055 \%$ ) and a mixture of feruloylquinic acids $(0.081 \%)$ for 6 days. Mice livers were removed and homogenized in Tris-HCl buffer ( $\mathrm{pH} 7.4$ ) weighing 6fold that of liver weight containing $0.25 \mathrm{M}$ sucrose and 1 $\mathrm{mM}$ EDTA. The homogenate was centrifuged $(880 \times \mathrm{g}$, $4^{\circ} \mathrm{C}, 10 \mathrm{~min}$ ) and the supernatant was collected; this was followed by a second centrifugation $\left(11,770 \times \mathrm{g}, 4^{\circ} \mathrm{C}\right)$ to obtain mitochondrial fraction. The precipitate of the mitochondrial fraction was flushed and suspended in buffer to obtain a protein concentration of $6 \mathrm{mg} / \mathrm{mL}$. CPT activity was measured according to the method described by Markwell et al. [16]. Tris buffer ( $58 \mathrm{mM}$, pH 8.0, $1 \mathrm{~mL}$ ) containing $1.25 \mathrm{mM}$ EDTA, $0.1 \%$ Triton X-100 and 0.25 $\mathrm{mM}$ DTNB, $37.5 \mu \mathrm{M}$ palmitoyl CoA $(20 \mu \mathrm{L})$ and $6 \mathrm{mg} / \mathrm{mL}$ mitochondrial fraction $(20 \mu \mathrm{L})$ were mixed, and the optical density (OD) was recorded at $412 \mathrm{~nm}$ for $5 \mathrm{~min}$. Subsequently, $1.25 \mathrm{mM}$ L-carnitine $(20 \mu \mathrm{L})$ was added, and the OD was recorded for $5 \mathrm{~min}$. The CPT activity was calculated as follows:

CPT activity $(\mathrm{nmol} / \mathrm{min} / \mathrm{mg}$ protein $)=\frac{\left(\Delta \mathrm{OD}^{\mathrm{a}}-\Delta \mathrm{OD}^{\mathrm{b}}\right) \times 20^{\mathrm{c}} \times 10,000}{13,000^{\mathrm{d}} \times 6^{\mathrm{e}}}$

$\Delta \mathrm{OD}^{\mathrm{a}}$ : Linearity of optical density change for $1 \mathrm{~min}$ after addition of L-carnitine solution

$\Delta \mathrm{OD}^{\mathrm{b}}$ : Linearity of optical density change for $1 \mathrm{~min}$ at baseline

c: Volume of mitochondrial fraction $(\mu \mathrm{L})$

d: Molar extinction coefficient of palmitoyl-CoA

e: Protein contents in mitochondrial fraction (mg protein/ $\mathrm{mL}$ ) 
<smiles>Cn1c(=O)c2c(ncn2C)n(C)c1=O</smiles><smiles>O=C(O)O[C@H]1[C@@H](O)C[C@](O)(C(=O)O)C[C@@H]1OC(=O)/C=C/c1ccc(O)c(O)c1</smiles><smiles>O=C(/C=C/c1ccc(O)c(O)c1)O[C@@H]1C[C@](O)(C(=O)O)C[C@H](O)[C@H]1O</smiles>
3-caffeoylquinc acid (neochlorogenic acid)<smiles>COc1cc(/C=C/C(=O)O[C@H]2[C@H](O)C[C@](O)(C(=O)O)C[C@H]2O)ccc1O</smiles><smiles>O=C(/C=C/c1ccc(O)c(O)c1)O[C@H]1[C@@H](O)C[C@@](O)(C(=O)O)C[C@H]1OC(=O)/C=C/c1ccc(O)c(O)c1</smiles>

3,4-dicaffeoylquinc acid<smiles>O=C(/C=C/c1ccc(O)c(O)c1)O[C@H]1C[C@](O)(C(=O)O)C[C@@H](OC(=O)/C=C/c2ccc(O)c(O)c2)[C@H]1O</smiles>

3,5-dicaffeoylquinc acid<smiles>O=C(/C=C/c1ccc(O)c(O)c1)O[C@@H]1C[C@](O)(C(=O)O)C[C@@H](O)[C@H]1OC(=O)/C=C/c1ccc(O)c(O)c1</smiles>

4,5-dicaffeoylquinc acid

\section{Figure 2}

Chemical structures of constituents of GCBE.

\section{Statistics}

The results were expressed as mean \pm SE. Significance of the differences was examined using the one-way ANOVA method, followed by Dunnett's test. Results with $p<0.05$ were considered significant.

\section{Results}

Effect on body weight and visceral fat accumulation in mice

The changes in mice body weight and visceral fat content during the 14-day treatment with GCBE are tabulated in Table 1 . The amount of diet intake was not reduced during the GCBE treatment. GCBE $(0.5 \%$ and $1 \%)$ significantly suppressed mice body weight. The weight of mice epididy- mal and perirenal fats was significantly reduced in the group treated with GCBE $(0.5 \%)$. However, the results for the effect of caffeine $(0.05 \%$ and $0.1 \%)$ on the suppression of body weight and visceral fat were not significant. Chlorogenic acid (0.15\% and $0.3 \%)$ demonstrated a weak suppressive effect on body weight and perirenal fat accumulation. Orlistat $(0.1 \%)$, the positive control, showed a slight suppressive effect on epididymal and perirenal fat accumulation but no suppressive effect on body weight.

\section{Effect on hepatic TG accumulation in mice}

The hepatic TG levels in mice were reduced after a 13-day treatment with GCBE, caffeine and chlorogenic acid. Figure 3 illustrates the effect of GCBE, caffeine and chloro- 
Table I: Effects of GCBE and its constituents on body weight gain and accumulation of visceral fats

\begin{tabular}{|c|c|c|c|c|}
\hline & Content in diet (\%) & $\begin{array}{l}\text { Mean total food intake (g/ } \\
\text { body) }\end{array}$ & $\begin{array}{l}\text { Initial body weight Day } 0 \\
\text { (g) }\end{array}$ & $\begin{array}{l}\text { Final body weight Day } 14 \\
\text { (g) }\end{array}$ \\
\hline Control & -- & 75.3 & $28.2 \pm 0.6$ & $37.5 \pm 1.6$ \\
\hline \multirow[t]{2}{*}{ GCBE } & 0.5 & 80.0 & $27.3 \pm 0.5$ & $33.2 \pm 0.6 *$ \\
\hline & 1 & 75.5 & $26.9 \pm 0.7$ & $32.8 \pm 1.2 * *$ \\
\hline \multirow[t]{2}{*}{ Caffeine } & 0.05 & 74.9 & $27.0 \pm 0.4$ & $35.0 \pm 1.0$ \\
\hline & 0.1 & 74.3 & $26.6 \pm 0.4$ & $33.9 \pm 0.7$ \\
\hline \multirow[t]{2}{*}{ Chlorogenic acid } & 0.15 & 81.3 & $27.3 \pm 0.5$ & $35.2 \pm 0.5$ \\
\hline & 0.3 & 76.5 & $26.4 \pm 0.3$ & $34.5 \pm 0.5$ \\
\hline Control & -- & 73.8 & $26.8 \pm 0.4$ & $34.6 \pm 1.2$ \\
\hline \multirow[t]{3}{*}{ Orlistat } & 0.05 & 82.4 & $27.0 \pm 0.2$ & $35.0 \pm 0.4$ \\
\hline & 0.1 & 81.3 & $26.3 \pm 0.2$ & $34.2 \pm 1.0$ \\
\hline & Content in diet (\%) & Body weight gain (g) & Epididymal fat (mg) & Perirenal fat (mg) \\
\hline Control & -- & $9.3 \pm 0.4$ & $605 \pm 71$ & $223 \pm 39$ \\
\hline \multirow[t]{2}{*}{ GCBE } & 0.5 & $6.0 \pm 0.1 *$ & $393 \pm 59 *$ & $106 \pm 20 *$ \\
\hline & 1 & $5.8 \pm 0.2 *$ & $448 \pm 68$ & $124 \pm 23$ \\
\hline \multirow[t]{2}{*}{ Caffeine } & 0.05 & $8.0 \pm 0.2$ & $536 \pm 57$ & $146 \pm 29$ \\
\hline & 0.1 & $7.3 \pm 0.2$ & $491 \pm 39$ & $150 \pm 20$ \\
\hline \multirow[t]{2}{*}{ Chlorogenic acid } & 0.15 & $7.9 \pm 0.1$ & $574 \pm 48$ & $173 \pm 24$ \\
\hline & 0.3 & $8.1 \pm 0.1$ & $605 \pm 82$ & $175 \pm 25$ \\
\hline Control & -- & $7.8 \pm 0.9$ & $588 \pm 55$ & $249 \pm 60$ \\
\hline \multirow[t]{2}{*}{ Orlistat } & 0.05 & $8.1 \pm 0.4$ & $612 \pm 56$ & $251 \pm 45$ \\
\hline & 0.1 & $7.8 \pm 0.9$ & $48 I \pm 51 *$ & $180 \pm 33 *$ \\
\hline
\end{tabular}

Mice were fed non-purified diet (CE-2) containing each sample for 14 days. Each value represents the mean \pm SE of 6 to 7 mice. The asterisks denote a significant differences from the control group, *: $p<0.05$ and $* *: p<0.01$.

genic acid on hepatic TG. GCBE and caffeine showed a tendency to suppress hepatic TG. Further, the level of hepatic TG was significantly reduced by chlorogenic acid $(60 \mathrm{mg} / \mathrm{kg} \cdot$ day), suggesting its role in the suppression of hepatic TG in the group treated with GCBE.

\section{Effect on elevated serum TG level in olive oil-loaded mice}

The effects of GCBE and its constituents on fat absorption were examined in olive oil -loaded mice. The level of serum TG after fasting for $22 \mathrm{~h}$ was 60 to $125 \mathrm{mg} / \mathrm{dL}$. The results showed that the elevated serum TG level was significantly lowered in groups treated with GCBE (200 and $400 \mathrm{mg} / \mathrm{kg}$ ) as illustrated in Figure 4. Similarly, caffeine (20 and $40 \mathrm{mg} / \mathrm{kg}$ ) also showed a suppressive effect on the increase in serum TG levels. However, chlorogenic acid at concentrations of 60 and $120 \mathrm{mg} / \mathrm{kg}$ did not affect serum TG levels. Caffeine is suggested to be the contributing compound for the suppression of fat absorption in GCBEtreated mice. Elevated serum TG level was completely suppressed by orlistat $(60 \mathrm{mg} / \mathrm{kg})$.

\section{Effect on hepatic CPT activity in mice}

Part of the fatty acid metabolized and released from the adipose tissue is transferred to the liver for the oxidation process in the mitochondria of hepatocytes. CPT is a ratelimiting enzyme that catalyses the transportation of fatty acid to mitochondria for $\beta$-oxidation. As shown in Figure 5 , GCBE $(0.5 \%$ and $1 \%)$ demonstrated a dose-dependent enhancement of CPT activity in the liver mitochondria. Neochlorogenic acid $(0.028 \%$ and $0.055 \%)$ and feruloylquinic acid mixture $(0.081 \%)$ significantly enhanced CPT activity. However, caffeine and chlorogenic acid had no effect on CPT activity in the liver mitochondria. Sesamin $(0.1 \%)$, the positive control, slightly enhanced the CPT activity.

\section{Discussion}

The results showed that consumption of GCBE for 14 days caused a suppressive effect on weight gain and visceral fat accumulation in mice. GCBE contains $10 \%$ caffeine and $27 \%$ chlorogenic acid as the principal constituents, and these constituents showed a tendency to suppress body weight gain and visceral fat accumulation. Thus, these constituents are suggested to be partially involved in the suppressive effect of GCBE on body weight gain and visceral fat accumulation. Caffeine is known to be a lipolytic compound. On the other hand, the effect of chlorogenic acid on body weight gain has not yet been established. Rodriguez de Sotillo and Hadley reported that serum and hepatic TG levels were lowered with intravenous administration of chlorogenic acid in Zucker fa/fa rats [17]. However, the TG level in the adipose tissue was not lowered. 


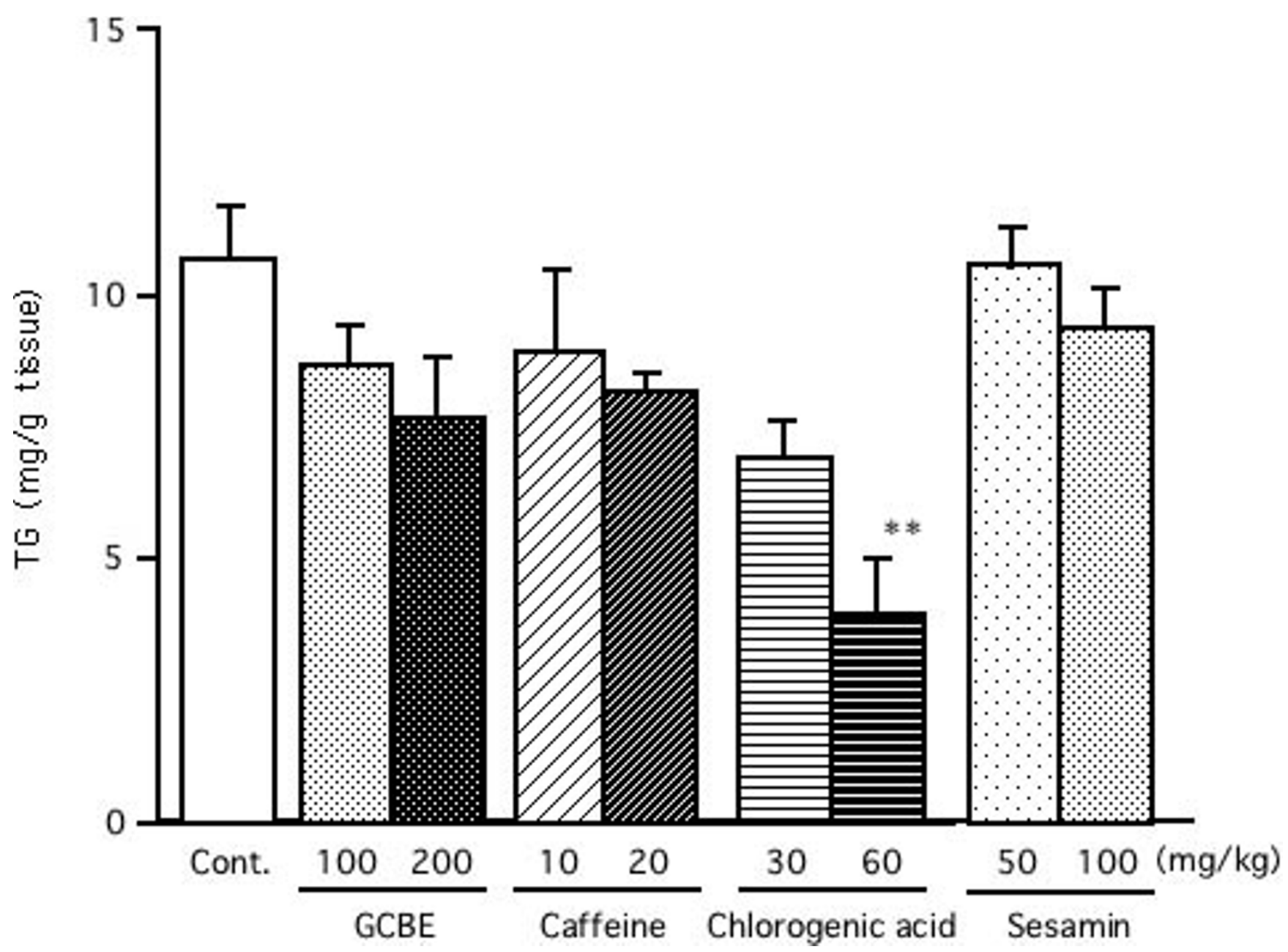

Figure 3

Effects of GCBE, caffeine, chlorogenic acid and sesamin on hepatic TG accumulation in mice. Each sample was administered once a day for 13 days. The columns represent the mean \pm SE of 7 mice. The double asterisks denote a significant difference from the control group, $* *: p<0.0$ I.

Therefore, chlorogenic acid is suspected to be effective on hepatic TG, and not adipose TG. In our study, both pure caffeine and chlorogenic acid alone did not significantly suppress weight gain or visceral fat accumulation. Recently, it was demonstrated that catechin and caffeine in green tea showed synergistic effects on enhancing fat expenditure in obese mice [18]. Chlorogenic acid is also a dietary polyphenolic compound with antioxidative activity. Thus, it is suggested that caffeine, chlorogenic acid and other polyphenolic compounds in GCBE act synergistically to suppress body weight gain and visceral fat accumulation in mice.

Additional experiments were conducted to examine the effect of GCBE and chlorogenic acid on hepatic TG accumulation. Oral administration of chlorogenic acid (30 and $60 \mathrm{mg} / \mathrm{kg}$. day) for 14 days reduced the level of hepatic TG in mice. However, the amount of visceral fat was unchanged (data not shown). The suppressive effect of chlorogenic acid on hepatic TG accumulation was more potent than that of GCBE. This result suggests that the TGlowering effect of GCBE is partially due to chlorogenic acid. The other constituents of GCBE, such as cafestol and kahweol, which promote synthesis of lipids [19], may cause discrepancy in the activities of GCBE (crude chlorogenic acid) and pure chlorogenic acid.

Further studies were prompted to examine the anti-obesity effect of GCBE on dietary fat absorption using olive oilloaded mice. The elevated serum TG level was lowered by GCBE and caffeine in olive oil-loaded mice. Coffee has been reported to delay gastric emptying [20]via constriction of smooth muscles in the proximal stomach. Hence, 
A) GCBE

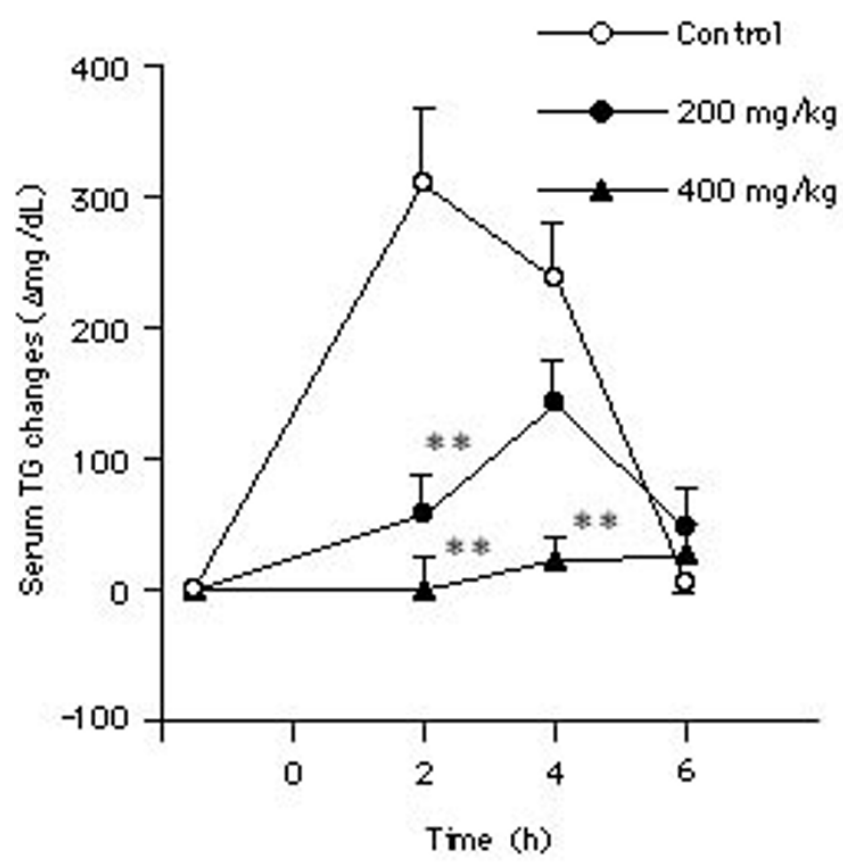

C) Chlorogenic acid

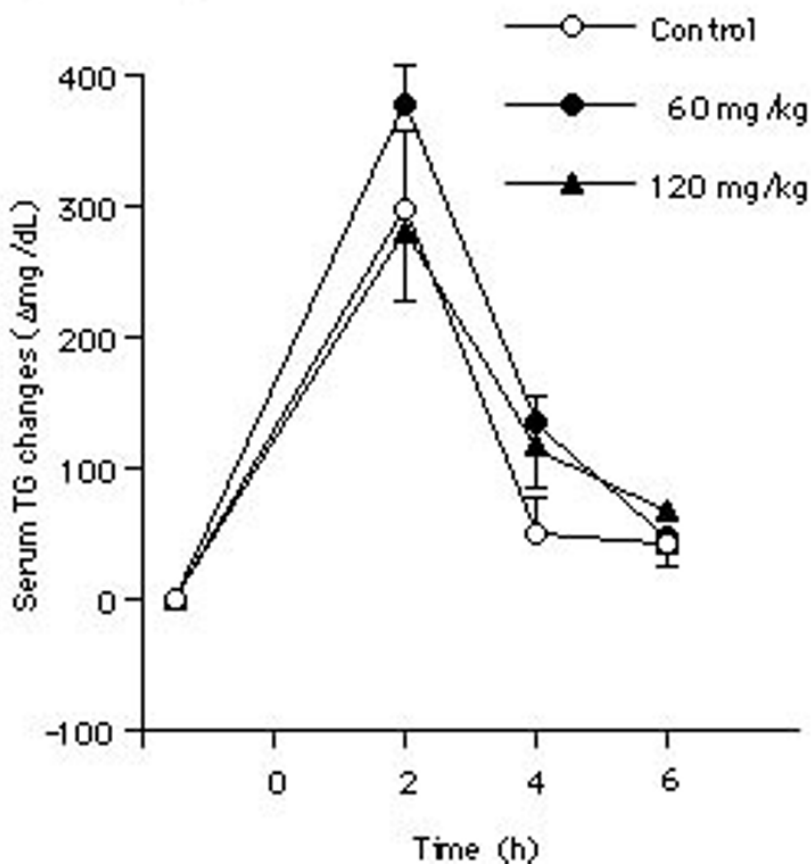

B) Caffeine

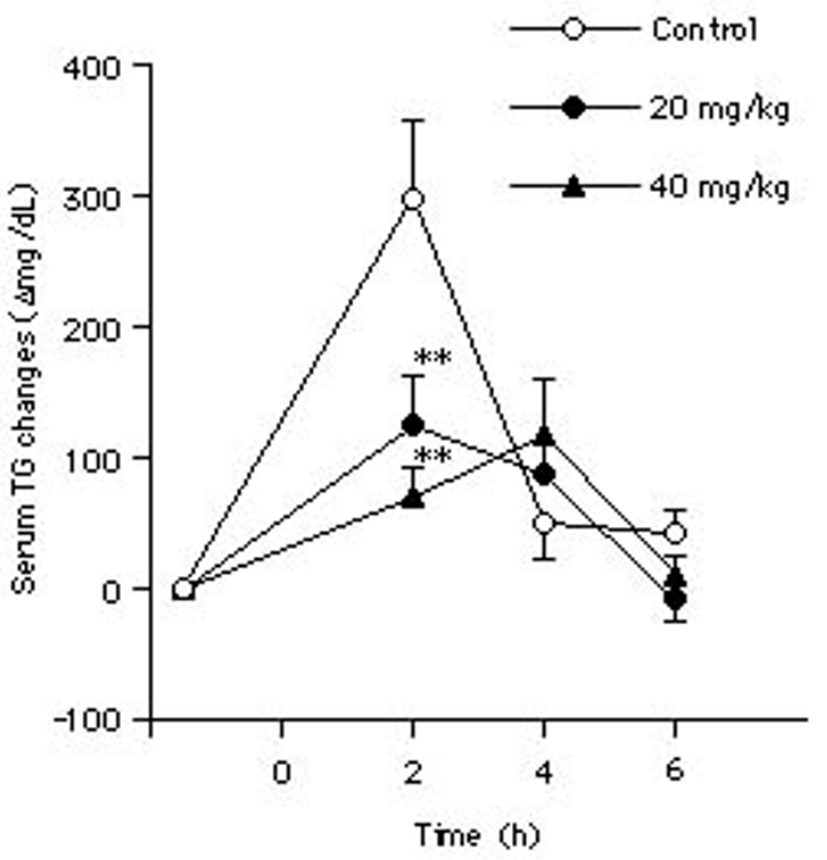

D) Orlistat

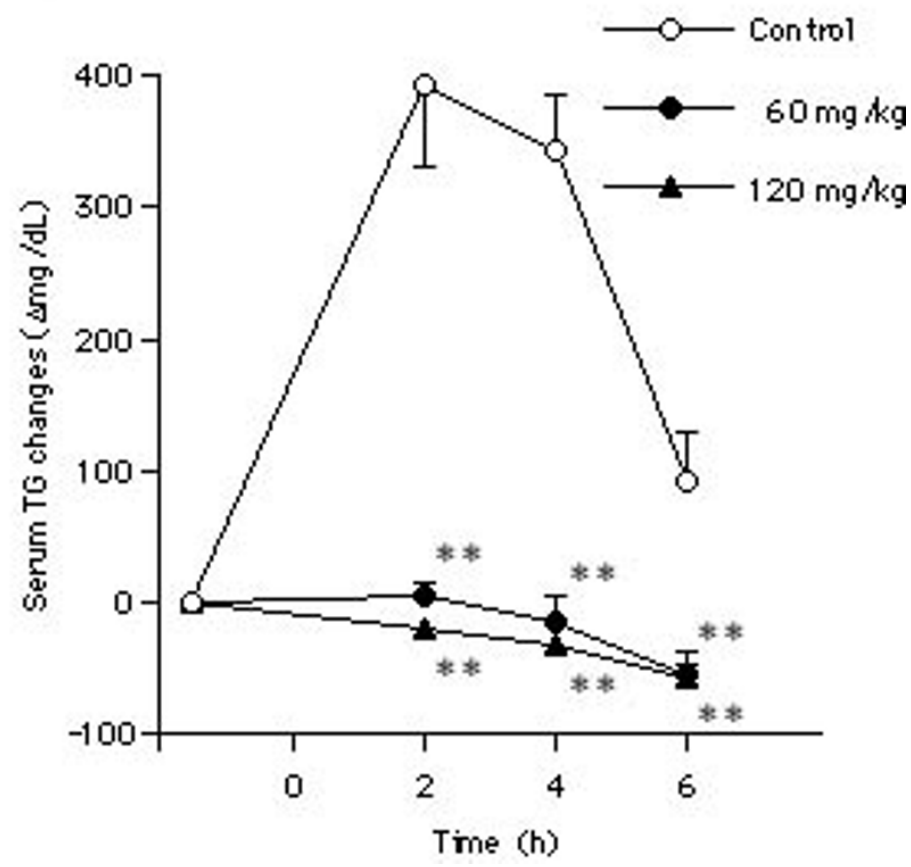

Figure 4

Inhibitory effects of GCBE, caffeine, chlorogenic acid and orlistat on serum TG elevation in olive oil-loaded mice. An initial blood sample was collected from each mouse, and each sample was orally administered $30 \mathrm{~min}$ later. After I h, olive oil was orally administered and a blood sample was collected every $2 \mathrm{~h}$. Symbols represent the mean \pm SE of 6 mice. The double asterisks denote a significant difference from the control group, $* *: p<0.01$. 
A)

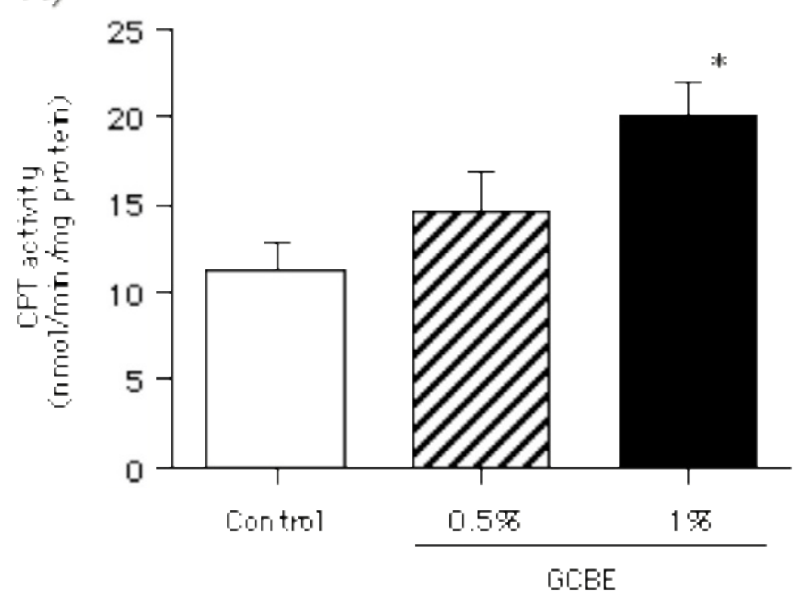

C)

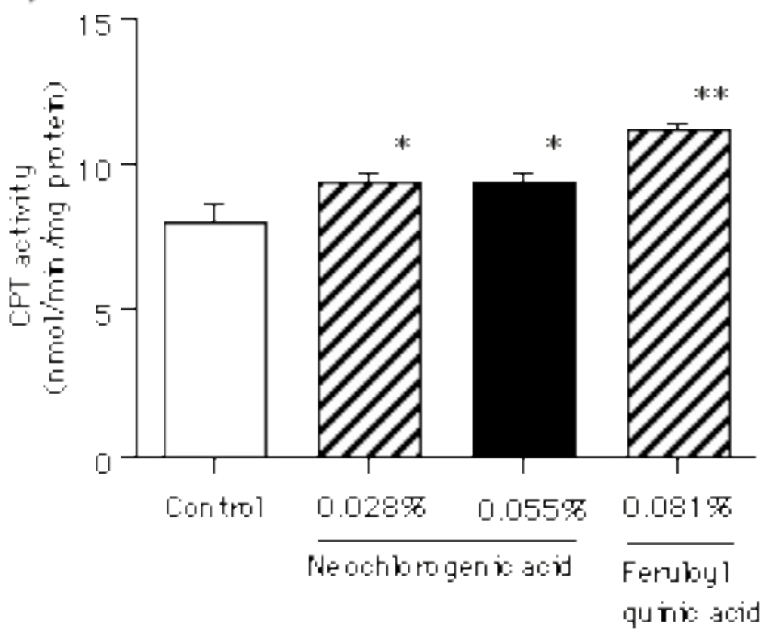

B)

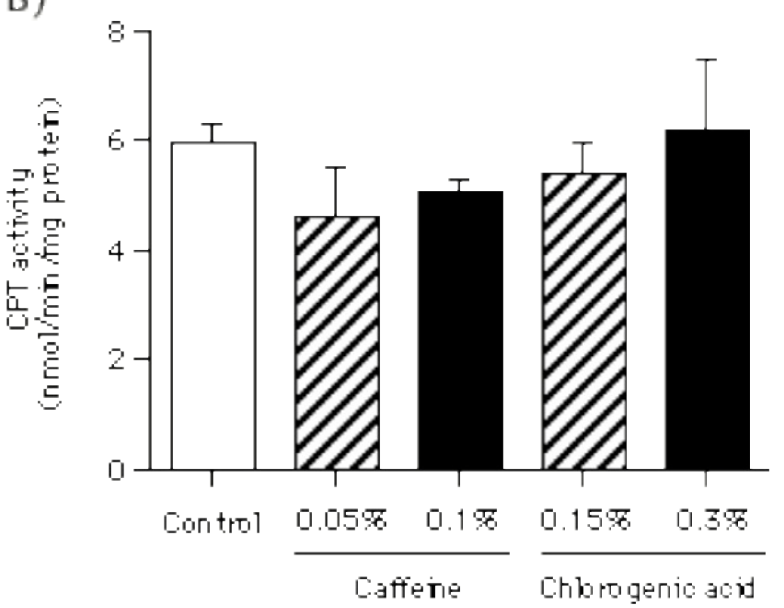

D)

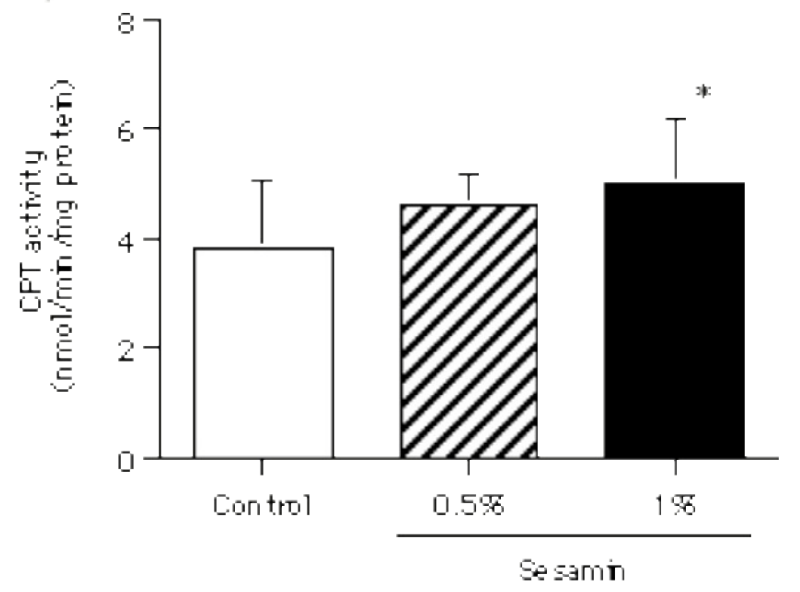

Figure 5

Effects of GCBE, its constituents and sesamin on hepatic CPT activity in mice. Mice were allowed free access to a diet containing each sample for 6 days. The CPT activity in the liver mitochondrial fraction was measured by the DTNB method. The columns represent the mean \pm SE of 4-5 mice. The asterisks denote a significant difference from the control group, *: $p<0.05$ and **: $p<0.01$.

caffeine is suggested to delay fat absorption leading to lowering of elevated serum TG level.

Finally, the effect of GCBE and its constituents on hepatic CPT activity was examined. CPT activity was enhanced after 6-day consumption of GCBE. However, no effect was observed when similar examinations were conducted using caffeine and chlorogenic acid alone. Other polyphenolic compounds, namely, neochlorogenic acid and feruloylquinic acid, were isolated, and their effects on CPT activity were assessed. The chemical structures of neochlorogenic acid and feruloylquinic acid are quite similar to chlorogenic acid. The stereo configuration of carboxylic acid and caffeic acid or ferulic acid conjugated to the quinic acid moiety are suggested to be involved in the expression of the activity. Although the latest findings have revealed that sesamin [21] and $\gamma$-linoleic acid [22] enhance CPT gene expression, only a few reports have described the effects of dietary polyphenolic compounds. Moreover, their structure-activity relationship with regard to CPT activity has not been established. Further studies are required to determine the CPT enhancing activity of chlorogenic acid and its related compounds in GCBE. 


\section{Conclusion}

We conclude that GCBE can suppress body weight gain and visceral fat accumulation in mice. Caffeine suppresses fat absorption, while chlorogenic acid and its related compounds are found to be involved in the enhancement of fat metabolism in the liver.

\section{Competing interests}

The author(s) declare that they have no competing interests.

\section{Authors' contributions}

The experiments were designed by HS.

The experiments on animal models were performed by HS, ES and MA.

The determination of GCBE constituents was performed by HS and ES.

The manuscript was written by HS.

\section{Acknowledgements}

None

\section{References}

I. Panagiotakos DB, Pitsavos C, Chrysohoou C, Kokkinos P, Toutouzas $P$, Stefanadis C: The J-shaped effect of coffee consumption on the risk of developing acute coronary syndromes: the CARDIO2000 case-control study. J Nutr 2003, I 33:3228-3232.

2. Rasch V: Cigarette, alcohol, and caffeine consumption: risk factors for spontaneous abortion. Acta Obstet Gynecol Scand 2003, 82:182-188.

3. Virtanen SM, Rasanen L, Aro A, Ylonen K, Lounamaa R, Akerblom HK, Tuomilehto J: Is children's or parents' coffee or tea consumption associated with the risk for type I diabetes mellitus in children? Childhood Diabetes in Finland Study Group. Eur J Clin Nutr 1994, 48:279-285.

4. Van Dam RM, Feskens EJ: Coffee consumption and risk of type 2 diabetes mellitus. Lancet 2002, 360:|477-|478.

5. Fredholm BB, Lindgren E: The effect of alkylxanthines and other phosphodiesterase inhibitors on adenosine-receptor mediated decrease in lipolysis and cyclic AMP accumulation in rat fat cells. Acta Pharmacol Toxicol 1984, 54:64-7I.

6. Arciero PJ, Gardner AW, Calles-Escandon J, Benowitz NL, Poehlman ET: Effects of caffeine ingestion on NE kinetics, fat oxidation, and energy expenditure in younger and older men. Am J Physiol 1995, 268: EI192-I198.

7. Ryan DH: Medicating the obese patient. Endocrinol Metab Clin North Am 1996, 25:989-1004.

8. De Matteis R, Arch JR, Petroni ML, Ferrari D, Cinti S, Stock MJ: Immunohistochemical identification of the $\beta_{3}$-adrenoceptor in intact human adipocytes and ventricular myocardium: effect of obesity and treatment with ephedrine and caffeine. Int J Obes Relat Metab Disord 2002, 26:1442-1450.

9. Greer F, Hudson R, Ross R, Graham T: Caffeine ingestion decrease glucose disposal during a hyperinsulinemic-euglycemic clamp in sedentary humans. Diabetes 200I, 50:2349-2354.

10. Ryu S, Choi SK, Joung SS, Suh H, Cha YS, Lee S, Lim K: Caffeine as a lipolytic food component increases endurance performance in rats and athletes. I Nutr Sci Vitaminol 2001, 47:139-146.

II. Arion WJ, Canfield WK, Ramos FC, Schindler PW, Burger HJ, Hemmerle $H$, Schubert G, Below P, Herling AW: Chlorogenic acid and hydroxynitrobenzaldehyde: new inhibitors of hepatic glucose 6-phosphatase. Arch Biochem Biophys 1997, 339:315-322.
12. Del Castillo MD, Ames JM, Gordon MH: Effect of roasting on the antioxidant activity of coffee brews. J Agric Food Chem 2002, 50:3698-3703.

13. Suzuki A, Kagawa D, Ochiai R, Tokimitsu I, Saito I: Green coffee bean extract and its metabolites have a hypotensive effect in spontaneously hypertensive rats. Hypertens Res 2002 , 25:99-107.

14. Iwai K, Kishimoto N, Kakino Y, Mochida K, Fujita T: In vitro antioxidative effects and tyrosinase inhibitory activities of seven hydroxycinnamoyl derivatives in green coffee beans. J Agric Food Chem 2004, 52:4893-4898.

15. Shimoda H, Ninomiya K, Nishida N, Yoshino T, Morikawa T, Matsuda $H$, Yoshikawa M: Anti-hyperlipidemic sesquiterpenes and new sesquiterpene glycosides from the leaves of artichoke (Cynara scolymus L.): structure requirement and mode of action. Bioorg Med Chem Lett 2003, 13:223-228.

16. Markwell MAK, MacGroarty EJ, Bieber LL, Tolbert NE: The subcellular distribution of carnitine acyltransferases in mammalian liver and kidney. J Biol Chem 1973, 248:3426-3432.

17. Rodriguez de Sotillo DV, Hadley M: Chlorogenic acid modifies plasma and liver concentrations of cholesterol, triacylglycerol, and minerals in (fa/fa) Zucker rats. J Nutr Biochem 2002, 13:717-726.

18. Zheng G, Sayama K, Okubo T, Juneja LR, Oguni I: Anti-obesity effects of three major components of green tea, catechins, caffeine and theanine, in mice. In Vivo 2004, I 8:55-62.

19. Post SM, de Roos B, Vermeulen M, Afman L, Jong MC, Dahlmans VEH, Havekes LM, Stellaard F, Katan MB, Princen HMG: Cafestol increases serum cholesterol levels in apolipoprotein $E * 3-L e i-$ den transgenic mice by suppression of bile acid synthesis. Arterioscler Thromb Vasc Biol 2000, 20:|55|-| 556.

20. Boekema PJ, Samsom M, van Berge Henegouwen GP, Smout AJ: Coffee and gastrointestinal function: facts and fiction. Scand J Gastroenterol Suppl 1999, 230:35-39.

21. Ide T: Effect of dietary $\alpha$-linolenic acid on the activity and gene expression of hepatic fatty acid oxidation enzymes. Biofactors 2000, 13:9-14.

22. Ide T: Nutritional regulation of hepatic fatty acid oxidation and synthesis. JJpn Soc Nutr Food Sci (in Japanese) 2002, 55:105-I I0.

\section{Pre-publication history}

The pre-publication history for this paper can be accessed here:

http://www.biomedcentral.com/1472-6882/6/9/prepub

Publish with BioMed Central and every scientist can read your work free of charge

"BioMed Central will be the most significant development for disseminating the results of biomedical research in our lifetime. "

Sir Paul Nurse, Cancer Research UK

Your research papers will be:

- available free of charge to the entire biomedical community

- peer reviewed and published immediately upon acceptance

- cited in PubMed and archived on PubMed Central

- yours - you keep the copyright
BioMedcentral 